\title{
Analisis Potensi Unggulan Kabupaten Kepulauan Yapen dalam Menopang Pembangunan Provinsi Papua Tahun 2004-2008
}

\author{
Agus Tri Basuki \\ Universitas Muhammadiyah Yogyakarta \\ e-mail:agustribasuki@yahoo.co.
}

Regency Kepulauan Yapen is a new regency as a result of regional separation and is located in the area which is very closely to the neck of the bird head of Papua Province. An economic development strategy of a region must be able to identify all economic potencies of the region. Using analyses of MRP, Shift Share, LQ, Overlay and Klassen Typology, this research explores the economic potencies of Regency Kepulauan Yapen. This research reveals that the Regency has economic advantages in most sectors, except those of mining and manufacturing industries. The most advantageous sectors are those of services, finance, service companies, and construction. Other advantageous sectors are those supporting tourist industries, such as trade, hotel and restaurants.

Keywords: economic development, economic potencies, advantages.

\section{Pendahuluan}

$\mathrm{P}$ embangunan daerah sebagai bagian in tegral dari pembangunan nasional yang dilaksanakan berdasarkan prinsip otonomi daerah dan pengaturan sumber daya nasional yang memberikan kesempatan bagi peningkatan demokrasi dan kinerja daerah untuk meningkatkan kesejahteraan masyarakat. Oleh karena itu, pembangunan ekonomi daerah merupakan bagian dari pembangunan daerah secara menyeluruh.

Dalam upaya mencapai tujuan pembangunan ekonomi daerah, kebijakan utama yang perlu dilakukan adalah mengusahakan semaksimal mungkin agar prioritas pembangunan daerah sesuai dengan potensi pembangunan yang dimiliki oleh daerah. Hal ini terkait dengan potensi pembangunan yang dimiliki setiap daerah sangat bervariasi, maka setiap daerah harus menentukan kegiatan sektor ekonomi yang dominan (Syafrizal, 1999).

Kebijakan pembangunan ekonomi daerah yang ditetapkan di suatu daerah harus disesuaikan dengan kondisi (masalah, kebutuhan, dan potensi) daerah yang bersangkutan. Oleh karena itu, penelitian yang mendalam tentang keadaan tiap daerah harus dilakukan untuk mendapatkan data dan informasi yang berguna bagi penentuan perencanaan pembangunan daerah yang bersangkutan (Arsyad, 1999). Perencanaan pembangunan ekonomi yang baik membutuhkan suatu perencanaan yang teliti dalam menggunakan sumber-sumber daya publik dan swasta serta sektor-sektor yang berperan dalam 
proses perencanaan. Melalui perencanaan pembangunan ekonomi daerah yang terarah, pembayar pajak dan penanaman modal serta penciptaan iklim dari kegiatan ekonomi yang baik maka pembangunan suatu daerah dapat dikatakan sebagai satu unit kesatuan yang memiliki keterkaitan antara satu sama lain.

Daerah otonom mempunyai kewenangan untuk mengatur dan melayani kepentingan masyarakat berdasarkan aspirasi masyarakat serta merencanakan pembangunan yang sesuai dengan peraturan perundangan-undangan. Berdasarkan hal tersebut, daerah perlu memiliki konsep utama dalam perencanaan pembangunan daerah yang memuat dasar filosofi, visi, misi, arah kebijakan, dan strategi pembangunan sebagai pedoman bagi penyelenggaraan pemerintahan dan pengelolaan pembangunan di daerah. Oleh karena itu, disadari bahwa pelaksanaan pembangunan daerah bukan merupakan tanggungjawab pemerintah secara kesuluruhan tetapi merupakan tanggung-jawab semua pihak dan masyarakat Kabupaten Kepulauan Yapen, sehingga hasil yang diperoleh dapat bermanfaat bagi semua pihak.

Keberhasilan pembangunan bidang ekonomi di Kabupaten Kepulauan Yapen dicerminkan oleh Produk Domestik Regional Bruto (PDRB), baik besaran nilai nominal maupun dari besaran pertumbuhan ekonomi. Pertumbuhan ekonomi dapat meningkatkan perluasan kesempatan kerja, mengurangi pengangguran, dan secara makro akan menurunkan tingkat kemiskinan atau meningkatkan kesejahteraan. Permasa-lahan akan muncul jika peningkatan produksi dibawa ke luar wilayah dan dapat dimanfaatkan oleh penduduk di luar wilayah tersebut, maka pertumbuhan ekonomi merupakan sebuah upaya untuk mening-katkan kesejahteraan masyarakat di suatu wilayah.
Keadaan perekonomian Kabupaten Kepulauan Yapen Tahun 2008 tidak mengalami perubahan yang signifikan dibandingkan dengan tahun-tahun sebelumnya, usaha pemerintah, pihak legislatif dan swasta dalam memacu pertumbuhan ekonomi belum mencapai hasil yang maksimal, sehingga masih diperlukan berbagai usaha untuk mencapai pertumbuhan di semua sektor. Karena dengan pertumbuhan sektor-sektor ekonomi diharapkan dapat membuka lapangan kerja baru yang akan berdampak positip bagi kesejahteraan masyarakat. Walaupun secara umum pemberlakuan otonomi khusus di tanah Papua berimplikasi positif bagi kemajuan perekonomian. Hal ini ditandai dengan membaiknya beberapa indikator makro ekonomi seperti pertumbuhan perekonomian, tingkat kemakmuran dan semakin bergesernya struktur perekonomian dari struktur primer menuju struktur sekunder.

Pertumbuhan riil PDRB Kabupaten Kepulauan Yapen tahun 2008 lebih rendah dibandingkan tahun sebelumnya yaitu sebesar 6,06 prosen. Tahun 2007 pertumbuhan PDRB Kabupaten Kepulauan Yapen sebesar 6,77 prosen, lebih tinggi dibandingkan tahun 2006 yang sebesar 6,17 persen (Yapen dalam angka 2008).

Dari sembilan sektor yang membentuk PDRB, untuk tahun 2008 ini sektor pertanian, sektor industri pengolahan, dan sektor keuangan, persewaan dan jasa perusahaan mengalami peningkatan pertumbuhan, sedangkan untuk enam sektor lainnya yaitu sektor pertambangan dan penggalian, sektor listrik dan air bersih, sektor bangunan, sektor perdagangan, hotel dan restoran, sektor pengangkutan dan komunikasi, serta sektor jasa-jasa mengalami perlambatan pertumbuhan secara riil. 
Analisis Potensi Unggulan Kabupaten Kepulauan Yapen: Agus Tri Basuki

Dari uraian pendahuluan di atas, penulis terdorong untuk menganalisis dan mengkaji lebih lanjut mengenai sektor-sektor ekonomi yang menjadi pendorong pembangunan ekonomi di Kabupaten Kepulauan Yapen.

Mengingat ruang lingkup pembangunan ekonomi daerah sangat luas maka penulis membatasi pembahasan masalah pada sektor-sektor ekonomi yang ada di Kabupaten Kepulauan Yapen dan data yang digunakan adalah data tahunan dari tahun 2004 sampai dengan tahun 2008.

Berdasarkan latar belakang di atas, maka rumusan masalah yang akan dibahas dalam penelitian ini adalah:

1. Sektor ekonomi manakah yang menjadi sektor unggulan dalam pembangunan daerah di Kabupaten Kepulauan Yapen dengan menggunakan beberapa alat analisis alternatif?

2. Bagaimana pertumbuhan sektor-sektor ekonomi di Kabupaten Kepulauan Yapen menggunakan analisis Model Rasio Pertumbuhan (MRP)?

\section{Tujuan Penelitian}

Berdasarkan perumusan masalah di atas, maka tujuan penelitian ini adalah:

1. Untuk menganalisis dan mengetahui sektor-sektor ekonomi yang menjadi sektor unggulan dalam pembangunan daerah di Kabupaten Kepulauan Yapen dengan menggunakan beberapa alat analisis alternatif.

2. Untuk mengetahui pertumbuhan sektorsektor ekonomi berdasarkan kondisi PDRB di Kabupaten Kepulauan Yapen menggunakan analisis Model Rasio Pertumbuhan (MRP).

\section{Kajian Pustaka}

\section{Teori Pertumbuhan Ekonomi Daerah}

Ada beberapa teori dalam pertumbuhan ekonomi regional atau daerah, yang diuraikan seperti dibawah ini:

\subsection{Teori Ekonomi Neo Klasik}

Teori Neo Klasik ini memberikan dua konsep pokok dalam pembangunan ekonomi daerah yaitu keseimbangan (equilibrium) dan mobilitas faktor produksi. Artinya, sistem perekonomian akan mencapai keseimbangan alamiah jika modal bisa mengalir tanpa pembatasan. Oleh karena itu, modal akan mengalir dari daerah yang berupah tinggi ke daerah yang berupah rendah. Kaum klasik percaya bahwa perekonomian yang dilandaskan pada kekuatan mekanisme pasar akan menuju keseimbangan. Dalam hal ini, kegiatan produksi secara otomatis akan menciptakan daya beli untuk membeli barangbarang yang dihasilkan. Dalam posisi keseimbangan tidak terjadi kelebihan maupun kekurangan permintaan. Ketidakseimbangan (disequilibrium), seperti pasokan lebih besar dari permintaan, kekurangan konsumsi, atau terjadi pengangguran, keadaan ini dinilai kaum klasik sebagai suatu yang sifatnya sementara. Nanti akan ada suatu tangan yang tak kentara (invisiblehands) yang akan membawa perekonomian kembali pada sisi keseimbangan.

\subsection{Teori Basis Ekonomi (Economic Ba- sic Theory) \\ Teori basis ekonomi ini menyatakan bahwa faktor penentu utama pertumbuhan ekonomi suatu daerah adalah berhubungan langsung dengan permintaan akan barang}


dan jasa dari luar daerah (Arsyad, 1999). Teori basis ini dibagi menjadi dua sektor yaitu sektor basis dan sektor non basis. Sektor basis adalah suatu sektor ekonomi yang dapat mengekspor barang dan jasa keluar daerah perekonomian. Sedangkan sektor non basis adalah sektor atau kegiatan barang dan jasa yang dibutuhkan oleh masyarakat.

Teori ini didasarkan pada teori lokasi, yaitu pertumbuhan ekonomi suatu daerah akan banyak ditentukan oleh jenis lokasi yang selanjutnya dapat digunakan daerah tersebut sebagai kekuatan ekspor, sehingga dalam menentukan strategi pembangunan harus disesuaikan dengan keuntungan lokasi yang dimiliki guna meningkatkan pertumbuhan ekonomi daerah.

\subsection{Teori Lokasi}

Teori ini mengemukakan tentang pemilihan lokasi yang dapat meminimumkan biaya. Lokasi optimum dari suatu perusahaan atau industri umumnya terletak atau berdekatan dengan pasar atau sumber bahan baku. Artinya, semakin tepat pemilihan lokasi yang strategis maka semakin kecil biaya produksi yang dikeluarkan. Ada beberapa variabel yang mempengaruhi kualitas suatu lokasi misalnya upah tenaga kerja, biaya energi, ketersediaan pemasok, komunikasi, pendidikan dan pelatihan, kualitas pemerintah daerah dan tanggung jawab serta sanitasi. Keterbatasan dari teori lokasi ini pada saat sekarang adalah bahwa teknologi dan komunikasi modern telah mengubah signifikansi suatu lokasi tertentu untuk kegiatan produksi dan distribusi barang.

\subsection{Teori Tempat Sentral (Central Place} Theory)

Teori tempat sentral menganggap bahwa ada semacam hirarki tempat (hierarchy of places) yang didukung oleh sejumlah tempat yang menyediakan sumber daya industri dan bahan baku. Tempat sentral tersebut merupakan suatu pemukiman yang menyediakan jasa-jasa bagi penduduk daerah yang mendukungnya.

Teori tempat sentral bisa diterapkan pada pembangunan ekonomi daerah, baik daerah pedesaan maupun perkotaan. Beberapa daerah bisa menjadi wilayah penyedia jasa sedangkan lainya hanya sebagai daerah pemukiman. Seorang ahli ekonomi pembangunan ekonomi daerah dapat membantu masyarakat untuk mengembangkan peranan fungsional mereka dalam sistem ekonomi daerah.

\subsection{Teori Kausasi Kumulatif}

Kondisi daerah-daerah sekitar kota yang semakin buruk menunjukkan konsep dasar mirip teori kausasi kumulatif. Dengan kata lain, kekuatan-kekuatan pasar cenderung memperparah kesenjangan daerah-daerah tersebut. Daerah yang maju mengalami akumulasi keunggulan kompetitif dibandingkan daerah-daerah lainya.

\subsection{Teori Model Daya Tarik (Attraction)}

Teori model daya tarik adalah model pembangunan ekonomi yang paling banyak dipergunakan oleh masyarakat atau teori ini disebut juga teori daya tarik industri. Teori ekonomi yang mendasarinya adalah bahwa suatu masyarakat dapat memperbaiki posisi pasar terhadap industrialis melalui pemberian subsidi dan intensif.

\section{Perencanaan Pembangunan Ekonomi Daerah}

Perencanaan adalah suatu proses yang bersinambung yang mencakup keputusankeputusan atau pilihan-pilihan berbagai alternatif penggunaan sumber daya untuk mencapai tujuan tertentu pada masa yang akan datang (Conyers \& Hill, 1994). 
Analisis Potensi Unggulan Kabupaten Kepulauan Yapen: Agus Tri Basuki

Tujuan perencanaan menurut Mohammad Hatta adalah mengadakan suatu perekonomian nasional yang diatur, yang direncanakan tujuannya dan jalannya. Sedangkan menurut Widjojo Nitisastro, perencanaan pada dasarnya berkaitan dengan dua hal yaitu pertama adalah penentuan pilihan yang hendak dicapai dalam jangka waktu tertentu atas dasar nilai yang dimiliki masyarakat yang bersangkutan. Kedua, pilihan-pilihan diantara cara-cara alternatif yang efisien guna mencapai tujuan tertentu. Dalam hal ini, untuk penentuan tujuan yang meliputi jangka waktu tertentu maupun bagi pemilihan cara-cara tersebut diperlukan kriteria tertentu yang sebelumnya harus dipilih terlebih dahulu.

Perencanaan ekonomi terdiri atas sederetan fungsi kewenangan masyarakat dalam menggunakan sumber daya ekonomi secara optimal untuk mencapai suatu tatanan yang lebih baik. Dengan demikian, perencanaan ekonomi merupakan pengaturan dan pengarahan atas suatu kegiatan ekonomi melalui tindakan yang terkoordinasi secara sistematis oleh badan perencanaan pusat dengan tujuan tertentu dalam periode waktu tertentu.

Dalam usaha pelaksanaan pembangunan sekarang ini belum berjalan dengan baik karena perencanaan ekonomi yang ada belum dapat memberikan gambaran dari berbagai indikator ekonomi dalam suatu pembangunan. Perencanaan pembangunan ekonomi ini ditandai dengan adanya usaha untuk memenuhi ciri-ciri tertentu dan tujuan yang bersifat pembangunan tertentu. Hal ini yang membedakan perencanaan pembangunan dengan perencanaan-perencanaan yang lain.

Perencanaan pembangunan ekonomi daerah bukanlah perencanaan dari suatu daerah. Perencanaan pembangunan ekonomi daerah bisa dianggap sebagai perencanaan untuk memperbaiki kapasitas sektor swasta dalam menciptakan nilai sumber-sumber daya swasta secara bertanggung jawab (Kuncoro, 2004).

\section{Sumber Daya Perencanaan Untuk Pembangunan Daerah}

Kebanyakan orang mengetahui bahwa hasil dari suatu pertumbuhan ekonomi, pekerjaan yang lebih banyak dan lebih baik, peningkatan kekayaan dan pendapatan, dan sebagainya akan memperbaiki tingkat kehidupan masyarakat. Namun demikian, disadari, bahwa pembangunan ekonomi adalah suatu proses dimana suatu masyarakat menciptakan lingkungan fisik atau peraturan yang mempengaruhi hasilhasil pembangunan ekonomi seperti kenaikan kesempatan kerja dan pertumbuhan ekonomi (Arsyad, 1999), maka pemerintah daerah menggunakan berbagai sumber daya yang utama dalam pembangunan daerahnya.

\subsection{Lingkungan Fisik sebagai Sumber Daya Perencanaan \\ Pemerintah daerah biasanya memper-} hatikan masalah lingkungan fisik dan infrastruktur fisik yang tentu saja merupakan hal yang penting bagi dunia usaha dan industri. Sektor swasta biasanya memiliki keinginan-keinginan yang bersifat khusus maupun umum dan persyaratan-persyaratan tertentu untuk lingkungan fisik. Kebutuhan khusus biasanya mencakup jasa angkutan khusus atau jasa pembuangan limbah. Bentuk-bentuk lingkungan fisik ini bisa dibuat sama. Dengan kata lain, pemerintah daerah bisa menyediakan jasa atau fasilitas khusus untuk memenuhi keinginan dunia usaha atau industri. Salah satu faktor yang 
mempengaruhi keputusan lokasi dari investasi sektor swasta adalah daya tarik (attraction) dari suatu daerah. Bentuk dari daya tarik ini sering disebut kualitas hidup yang sangat penting bagi dunia industri dan bagi pemerintah daerah memberikan posisi untuk memperbaiki kualitas hidup masyarakat.

\subsection{Lingkungan Regulasi sebagai Sumber Daya Perencanaan}

Pemahaman bahwa insentif dan kebijakan-kebijakan keuangan merupakan input penting bagi proses pembangunan ekonomi. Kebanyakan pemerintah daerah mengkaji ulang sistem regulasinya untuk menunjukkan bahwa biaya untuk melakukan kegiatan usaha di daerah untuk mencapai pertumbuhan ekonomi tetapi itu hanya mencerminkan keinginan mereka. Dengan kata lain, untuk menarik dan mengembangkan dunia usaha di daerahnya, maka perlu adanya penyederhanaan dalam sistem regulasi.

\subsection{Lingkungan Attitudinal sebagai Sumber Daya Perencanaan}

Keputusan yang diambil sektor swasta mengenai investasi atau relokasi tidak hanya didasarkan pada perkataan kasar para investor yang tidak dimengerti oleh masyarakat atau penduduk suatu daerah. Dalam kenyataannya, keputusan akhir akan sangat dipengaruhi juga oleh semacam feeling atau judgment para investor mengenai reaksi masyarakat daerah sebagai calon lokasi investasi karena dunia usaha tidak akan memilih suatu daerah tertentu karena penduduknya.

\section{Peran Pemerintah dalam Pembangunan Daerah}

Tahap pertama perencanaan bagi setiap organisasi yang tertarik dalam pembangunan ekonomi daerah adalah menen- tukan peran (role) yang akan dilakukan dalam proses pembangunan. Ada 4 (empat) peran yang dapat diambil oleh pemerintah daerah dalam proses pembangunan ekonomi daerah yaitu sebagai entrepreneur, koordinator, fasilisator, dan stimulator bagi lahirnya inisiatif-inisiatif pembangunan daerah (Arsyad, 1999).

\section{Pembangunan Daerah di Era Otonomi}

Ditetapkannya Undang-Undang No. 32 Tahun 2004 tentang Pemerintah Daerah dan Undang-Undang No. 33 Tahun 2004 tentang Perimbangan Keuangan antara Pemerintah Pusat dan Pemerintah Daerah, telah memberikan kewenangan bagi pemerintah daerah untuk menyelenggarakan pemerintahannya sendiri untuk lebih memajukan dan melakukan pembangunan di daerah masing-masing.

Menurut Undang-Undang No.32 Tahun 2004; "Daerah Otonom adalah kesatuan masyarakat hukum yang mempunyai batasbatas yang berwenang mengatur dan mengurus urusan pemerintahan dan kepentingan masyarakat setempat menurut prakarsa sendiri berdasarkan aspirasi masyarakat dalam sistem Negara Kesatuan Republik Indonesia".

Sedangkan menurut Undang-Undang No.32 Tahun 2004 "Otonomi Daerah adalah hak, wewenang, dan kewajiban daerah otonom untuk mengatur dan mengurus sendiri urusan pemerintahan dan kepentingan masyarakat setempat sesuai dengan peraturan perundang-undangan".

Berdasarkan Undang-Undang tersebut, maka masing-masing daerah dituntut untuk lebih mandiri dalam menjalankan proses pembangunan daerahnya. Antara lain dalam perencanaan, pelaksanaan, pengawasan, pengendalian dan evaluasi kebijakan 
Analisis Potensi Unggulan Kabupaten Kepulauan Yapen: Agus Tri Basuki

pembangunan. Dengan demikian setiap daerah harus mampu berkreasi dan mengoptimalkan outputnya guna meningkatkan kemajuan dan kemandirian daerah serta meningkatkan kesejahteraan masyarakat di daerahnya.

Aparatur pemerintah yang berkemampuan, sehingga masyarakat secara nyata memperoleh manfaat dari adanya otonomi. Agar tujuan dan usaha pembangunan daerah dapat berhasil dengan baik maka pemerintah daerah perlu berfungsi dengan baik. Oleh karena itu, pembangunan daerah juga merupakan usaha mengembangkan dan memperkuat pemerintahan daerah dalam rangka penyelenggaraan otonomi daerah.

\section{Penyelenggaraan Otonomi Daerah}

Desentralisasi pada dasarnya merupakan suatu mekanisme atas pengelolaan kebijaksanaan dengan kewenangan yang lebih besar diberikan kepada daerah agar penyelenggaraan pemerintah dan pelaksanaan pembangunan lebih efektif dan efisien.

Dalam batas-batas yang disepakati, yakni bahwa otonomi tidak berarti terlepas dari Negara kesatuan dan kaidah-kaidah serta aturan-aturan yang mengikat bangsa ini menjadi satu, dan bahwa maksud diadakannya otonomi adalah demi kesejahteraan masyarakat di daerah dan di seluruh tanah air, maka desentralisasi di berbagai bidang itu akan berpengaruh positif bagi kehidupan berbangsa dan bernegara, bahkan mungkin bukan hanya keinginan melainkan suatu kebutuhan, karena perkembangan masyarakat serta lingkungan strategis mengharuskan kecepatan dalam mengatasi kendala dan memanfaatkan peluang. Di pihak lain, desentralisasi tidak juga mengakibatkan makin besarnya kesenjangan antar daerah, tetapi justru harus mampu mendekatkan taraf kemajuan daerah yang satu dengan daerah lainnya ( Kartasasmita, 1996).

Dalam rangka pembangunan nasional, penyelenggaraan dan perwujudan otonomi daerah perlu mempertimbangkan pengaruh dan hubungannya dengan aspek-aspek lain, yaitu sebagai berikut:

1) Hubungan globalisasi dan proses industrialisasi

2) Hubungan persatuan dan kesatuan bangsa

3) Hubungan dengan kencenderungan egalitarianisme

4) Hubungan dengan pemberdayaan rakyat

Inti dari konsep pelaksanaan otonomi daerah adalah upaya untuk memaksimalkan hasil yang akan dicapai sekaligus menghindari kerumitan dan hal-hal yang menghambat pelaksanaan otonomi daerah. Menurut Rasyid dan Paragon dikatakan, bahwa keberhasilan pelaksanaan otonomi daerah ditentukan oleh 5 (lima) faktor, yaitu:

1) Self Reguler Power, kemampuan mengatur dan melaksanakan otonomi daerah demi kepentingan masyarakat di daerah.

2) Self Modifiying Power, kemampuan menyesuaikan terhadap peraturan yang ditetapkan sesuai dengan kondisi daerah, termasuk penemuan baru yang inovatif ke arah kemajuan dalam menyikapi potensi daerah.

3) Creating Local Political Support, penyelenggaraan pemerintah daerah yang memiliki legimitasi yang kuat dari masyarakat.

4) Managing Financial Resources, mampu mengembangkan kompetensi dalam mengelola secara optimal sumber penghasilan dan keuangan guna membiayai aktifitas pemerintahan, 
pembangunan dan pelayanan kepada masyarakat.

5) Developing Brain Power, membangun sumber daya manusia yang handal dan selalu bertumpu pada kapasitas dan kapabilitas dalam menyelesaikan masalah yang terjadi di daerah.

Dalam pelaksanaan otonomi daerah yang ditentukan dari kelima faktor di atas maka faktor managing financial resources atau kemampuan dalam mengelola keuangan secara optimal sumber penghasilan sehingga pembangunan ekonomi daerah akan dapat berjalan dengan baik.

\section{Hasil Penelitian Terdahulu}

Sri Suharsih dan Ahmad Syari'uddin (2003) pernah meneliti, "Analisis Dalam Perencanaan Pembangunan Daerah Dengan Menggunakan Beberapa Alat Analisis: Studi Kasus Provinsi Daerah Yogyakarta, Pada PELITA VI". Penelitian ini diambil untuk menganalisis secara umum gambaran tentang sektor ekonomi di Provinsi DIY, penelitian ini juga untuk mengidentifikasi perkembangan potensi dan sektor ekonomi dalam perencanaan pembangunan serta pertumbuhan ekonomi di Provinsi DIY. Dalam penelitian ini di antaranya menggunakan alat analisis Model Rasio Pertumbuhan (MRP), analisis Location Quotient (LQ), analisis Overlay dan analisis Klassen Typology. Hasil penelitian ini menunjukkan, bahwa Provinsi DIY mempunyai keunggulan dalam perkembangan sektor sekunder dan tersier terutama seperti sektor industri pengolahan, transportasi dan telekomunikasi, dan sektor jasa. Dari hasil analisis dengan menggunakan metode Klassen Typology menunjukkan pertumbuhan yang cepat di sektor industri pengolahan, sektor perdagangan, hotel dan restoran, sektor keuangan, jasa perusahaan dan persewaan serta sektor jasa-jasa.
Penelitian oleh Liling Joko Suprapto (2007) "Analisis Perubahan Struktur Ekonomi dan Basis Ekonomi Provinsi DI Yogyakarta Tahun 1998-2004 (Implementasi Pelaksa-naan Otonomi Daerah). Penelitian ini merupakan penelitian deskriptif, dengan menggunakan data sekunder berupa variabel PDRB beserta komponen-komponennya di Provinsi DIY dan juga variabel PDB Indonesia antara era sebelum (1998-2000) dan pada era otonomi daerah (2001-2004). Adapun metode analisis data yang digunakan antara lain analisis Deskriptif, analisis Shift-Share E-M, analisis Indeks Konsentrasi, analisis Indeks Spesialisasi, analisis LQ, analisis MRP, dan analisis Overlay. Selain itu untuk menguji gambaran kinerja antara era sebelum dan pada era otonomi daerah digunakan analisis uji t untuk dua sampel berpasangan dan analisis uji t untuk dua sampel inde-penden (khusus pada hasil analisis LQ). Kesimpulan dari penelitian ini yaitu menge-tahui kinerja antara era sebelum dan pada era otonomi daerah digunakan analisis uji t untuk dua sampel berpasangan dan analisis uji t untuk dua sampel independen (khusus pada hasil analisis LQ). Dari hasil penelitian dengan menggabungkan hasil analisis LQ dan MRP didapat sektor ekonomi unggulan kontribusi (+) pertumbuhan (+) di Provinsi DIY pada era sebelum otonomi daerah adalah sektor pertanian, bangunan, perdagangan, pengangkutan, keuangan, dan jasa-jasa. Sedangkan pada era otonomi daerah sektor unggulannya adalah listrik, gas dan air minum, bangunan, perdagangan, dan keuangan.

\section{Metode Penelitian}

\section{Analisis Model Rasio Pertumbuhan (MRP)}

Analisis MRP merupakan alat analisis untuk melihat deskripsi kegiatan atau sektor ekonomi yang potensial berdasarkan pada 
kriteria pertumbuhan struktur ekonomi wilayah baik eksternal maupun internal (Yusuf, 1999).

Pendekatan analisis MRP ini dibagi menjadi dua rasio, yaitu: rasio pertumbuhan wilayah referensi $\left(R P_{R}\right)$ dan rasio pertumbuhan wilayah studi $\left(\mathrm{RP}_{\mathrm{S}}\right)$.

\section{a. Rasio Pertumbuhan Wilayah Referensi $\left(R P_{R}\right)$}

$\mathrm{RP}_{\mathrm{R}}$ adalah perbandingan antara laju pertumbuhan pendapatan kegiatan i di wilayah referensi dengan laju pertumbuhan total kegiatan (PDRB) wilayah referensi.

$$
\begin{aligned}
& \text { " } E_{i R} / E_{i R}(t) \\
& \mathrm{RP}_{\mathrm{R}}=\ldots \ldots \ldots \ldots \ldots \ldots \ldots \ldots \ldots \ldots
\end{aligned}
$$

Keterangan: " $\mathrm{E}_{\mathrm{iR}}=$ Perubahan pendapatan kegiatan i di wilayah referensi

$\mathrm{Ei}_{\mathrm{R}}(\mathrm{t})=$ Pendapatan kegiatan $\mathrm{i}$ awal periode penelitian di wilayah referensi

" $E_{R}=$ Perubahan PDRB di wilayah referensi $E_{R(t)}=$ PDRB pada awal penelitian wilayah referensi

Jika nilai $R P_{R}>1 P$ positif $(+)$, artinya menunjukkan bahwa pertumbuhan suatu sektor tertentu dalam wilayah referensi lebih tinggi dari pertumbuhan PDRB total wilayah referensi.

Jika nilai $R P_{R}<1$ P negatif ( - ), artinya menunjukkan bahwa pertumbuhan suatu sektor tertentu dalam wilayah referensi lebih kecil dari pertumbuhan PDRB total wilayah referensi.

\section{b. Rasio Pertumbuhan Wilayah Studi $\left(\boldsymbol{R} \boldsymbol{P}_{s}\right)$}

$\mathrm{RP}_{\mathrm{S}}$ adalah perbandingan antara laju pertumbuhan kegiatan i wilayah studi dengan laju pertumbuhan kegiatan i wilayah referensi.

$$
\begin{aligned}
& \text { “ Eij / E ij (t) } \\
& \mathrm{RP}_{\mathrm{S}}= \\
& \text { “ } \mathrm{Ei}_{\mathrm{R}} / \mathrm{Ei}_{\mathrm{R}}(\mathrm{t})
\end{aligned}
$$

Keterangan: " $\mathrm{Eij}=$ Perubahan pendapatan kegiatan i di wilayah studi

$\operatorname{Eij}(\mathrm{t})=$ Pendapatan kegiatan i pada awal periode penelitian wilayah studi

$" \mathrm{Ei}_{\mathrm{R}}=$ Perubahan pendapatan kegiatan i di wilayah referensi

$\mathrm{Ei}_{\mathrm{R}}(\mathrm{t})=$ Pendapatan kegiatan i awal periode penelitian di wilayah referensi

Jika nilai RPs $>1$ P positif $(+)$, artinya menunjukkan bahwa pertumbuhan sektor pada tingkat wilayah studi lebih tinggi dibandingkan dengan pertumbuhan sektor pada wilayah referensi.

Jika nilai RPs < 1 P negatif ( - ), artinya pertumbuhan suatu sektor pada tingkat wilayah studi lebih rendah dibandingkan dengan pertumbuhan sektor tersebut pada wilayah referensi.

\section{Analisis Shift Share}

Analisis Shift share merupakan teknik dalam menganalisis pertumbuhan ekonomi suatu daerah sebagai perubahan atau peningkatan suatu indikator pertumbuhan perekonomian suatu wilayah dalam kurun waktu tertentu. Tujuan analisis ini adalah untuk menentukan kinerja atau produktivitas kerja perekonomian daerah dibandingkan dengan perekonomian di tingkat regional atau nasional.

Analisis Shift share ini membagi pertumbuhan sebagai perubahan (D) suatu variabel daerah, seperti jumlah tenaga kerja, nilai tambah, pendapatan atau output selama waktu tertentu menjadi pengaruh-pengaruh 
pertumbuhan nasional $(\mathrm{N})$, bauran industri/ industry mix (M) dan keunggulan kompetitif (C). Pengaruh pertumbuhan nasional disebut proporsional shift atau bauran komposisi, dan pengaruh keunggulan kompetitif dinamakan differential shift atau regional share (Soepono, 1993).

Ada 2 (dua) indikator dari hasil perhitungan Shift share dalam perekono-mian suatu daerah, yaitu:

1) Jika nilai dari komponen pergeseran proporsional dari sektor $>0$, maka sektor yang bersangkutan mengalami pertumbuhan yang cepat dan memberikan pengaruh yang positif kepada perekonomian daerah, begitu juga sebaliknya.

2) Jika nilai komponen pergeseran diferensial suatu sektor $<0$, maka keunggulan komparatif dari sektor tersebut meningkat dalam pereko-nomian yang lebih tinggi, begitu juga sebaliknya.

\section{Analisis Location Quotient (LQ)}

Location Quotient (LQ) yaitu usaha untuk mengukur konsentrasi dari suatu kegiatan (industri) dalam suatu daerah dengan cara membandingkakan peranannya dalam perekonomian daerah itu dengan peranan kegiatan atau industri sejenis dalam perekonomian regional atau nasional. Analisis LQ digunakan untuk mengetahui seberapa besar tingkat spesialisasi sektor basis atau unggulan (leading sector). Indikator yang digunakan yaitu kesempatan kerja (tenaga kerja) dan Produk Domestik Regional Bruto (PDRB) suatu wilayah.

Analisis LQ merupakan suatu alat analisis untuk menunjukkan basis ekonomi suatu wilayah terutama dari kriteria kontribusi. Alat analisis ini juga dipakai untuk mengukur konsentrasi dari suatu kegiatan (industri) dalam suatu daerah itu dengan peranan kegiatan atau industri sejenis dalam perekonomian regional atau nasional. Perhitungan basis tersebut menggunakan variabel PDRB wilayah atas suatu kegiatan dalam struktur ekonomi wilayah.

Ada 3 (tiga) kategori hasil perhitungan Location Quotient (LQ) dalam perekonomian daerah, yaitu:

1) Jika nilai $L Q>1$, maka sektor yang bersangkutan di wilayah studi lebih berspesialisasi dibandingkan dengan wilayah referensi. Artinya, sektor tersebut dalam perekonomian daerah di wilayah studi memiliki keunggulan komparatif dan dikategorikan sebagai sektor basis.

2) Jika nilai $L Q<1$, maka sektor yang bersangkutan di wilayah studi kurang berspesialisasi dibandingkan dengan wilayah referensi. Sektor tersebut dikategorikan sebagai sektor non basis.

3) Jika nilai $L Q=1$, maka sektor yang bersangkutan baik di wilayah studi maupun di wilayah referensi memiliki peningkatan.

\section{Analisis Overlay}

Analisis Overlay ini dimaksudkan untuk menentukan sektor atau kegiatan ekonomi yang potensial berdasarkan kriteria pertumbuhan dan kriteria kontribusi dengan menggabungkan hasil dari Metode Rasio Pertumbuhan (MRP) dan metode Location Quotient (LQ). Metode ini mempunyai 4 (empat) penilaian atau kemungkinan, yaitu:

1) Pertumbuhan (+) dan kontribusi (+), menunjukkan suatu kegiatan yang sangat dominan baik dari pertumbuhan maupun dari kontribusi.

2) Pertumbuhan (+) dan kontibusi (-) menunjukkan suatu kegiatan yang 
Analisis Potensi Unggulan Kabupaten Kepulauan Yapen: Agus Tri Basuki

pertumbuhannya dominan tetapi kontribusinya kecil. Kegiatan ini perlu lebih ditingkatkan kontribusinya untuk menjadi kegiatan yang dominan.

3) Pertumbuhan (-) dan kontribusi (+) menunjukkan suatu kegiatan yang pertumbuhannya kecil tetapi kontribusinya besar. Kegiatan ini sangat memungkinkan, bahwa kegiatan sedang mengalami penurunan.

4) Pertumbuhan (-) dan kontribusi (-) menunjukkan suatu kegiatan yang tidak potensial baik dari kriteria pertumbuhan maupun dari kontribusi.

\section{Analisis Klassen Tyopology}

Analisis Klassen Tyopology digunakan untuk melihat gambaran tentang pola dan struktur pertumbuhan masing-masing sektor ekonomi. Gambaran tentang pola dan struktur pertumbuhan daerah ini, dapat dipergunakan untuk memperkirakan prospek pertumbuhan ekonomi daerah pada masa mendatang. Selain itu, hal tersebut juga dapat dipergunakan sebagai bahan pertimbangan dalam menentukan kebijaksanaan pembangunan daerah.

Dan dengan kata lain, dalam analisis terdapat empat klasifikasi sektor-sektor ekonomi yang mempunyai karakteristik yang berbeda yaitu, sektor tumbuh cepat (rapid growth sector), sektor tertekan (retarted sector), sektor sedang tumbuh (growing sector), sektor relatif tertinggal (relatively backward sector) yang dapat dilihat seperti dibawah ini:

\section{Pembahasan}

\section{Analisis Model Rasio Pertumbuhan (MRP)}

Analisis MRP merupakan alat analisis untuk melihat deskripsi kegiatan atau sektor ekonomi yang potensial berdasarkan pada kriteria pertumbuhan struktur ekonomi wilayah baik eksternal maupun internal. Model analisis ini diturunkan dari persamaan awal komponen utama dalam analisis Shift Share yaitu Differential Shift dan Proportionality Shift. Dalam analisis ini terdapat dua jenis rasio pertumbuhan yaitu Rasio Pertumbuhan Wilayah Referensi $\left(\mathrm{RP}_{\mathrm{R}}\right)$ yaitu Provinsi Papua dan Rasio Pertumbuhan Wilayah Studi $\left(R P_{S}\right)$ yaitu Kabupaten Kepulauan Yapen.

Hasil dari analisis MRP ini dapat diklasifikasikan sebagai berikut:

1) Sektor yang mempunyai nilai $R P_{R}$ positif (+) dan $\mathrm{RP}_{S}$ positif (+) berarti kegiatan tersebut pada tingkat Provinsi mempunyai pertumbuhan yang menonjol dan demikian pula pada tingkat kabupaten. Kegiatan ini selanjutnya disebut dominan pertumbuhan.

2) Sektor yang mempunyai nilai $R P_{R}$ positif (+) dan $\mathrm{RP}_{\mathrm{S}}$ negatif (-) berarti kegiatan tersebut pada tingkat Provinsi mempunyai pertumbuhan menonjol, namun pada tingkat kabupaten belum menonjol.

3) Sektor yang mempunyai nilai $R P_{R}$ negatif (-) dan $\mathrm{RP}_{S}$ positif (+) berarti kegiatan tersebut pada tingkat Provinsi mempunyai pertumbuhan tidak menonjol sementara pada tingkat kabupaten termasuk menonjol.

4) Sektor yang mempunyai nilai $R P_{R}$ negatif (-) dan $R P_{S}$ negatif (-) berarti kegiatan tersebut pada tingkat Provinsi dan pada tingkat kabupaten mempunyai pertumbuhan rendah.

Apabila nilai $R P_{R}$ atau $R P_{S}>1$ yaitu positif $(+)$, artinya menunjukkan, bahwa pertumbuhan suatu sektor tertentu dalam wilayah referensi lebih tinggi dari pertumbuhan PDRB total wilayah referensi. Sedangkan, apabila nilai $\mathrm{RP}_{\mathrm{R}}$ atau $\mathrm{RP}_{\mathrm{S}}<1$ 
yaitu negatif (-), artinya menunjukkan bahwa pertumbuhan suatu sektor tertentu dalam wilayah referensi lebih kecil dari pertumbuhan PDRB total wilayah referensi.

Di bawah ini merupakan hasil perhitungan dan analisis MRP Kabupaten Kepulauan Yapen untuk melihat deskripsi kegiatan atau sektor ekonomi terutama struktur ekonomi di wilayah ini. kabupaten. Dan sektor-sektor lainnya seperti sektor pertambangan dan penggalian, dan Sektor pengangkutan dan komunikasi, mempunyai nilai $\mathrm{RP}_{\mathrm{R}}$ positif dan nilai $\mathrm{RP}_{\mathrm{S}}$ negatif berarti sektor-sektor tersebut pada tingkat Provinsi mempunyai pertumbuhan yang menonjol tetapi pada tingkat kabupaten belum menonjol.

Tabel 1.Hasil Perhitungan MRP Kabupaten Kepulauan Yapen Tahun 2004-2008

\begin{tabular}{|c|c|c|c|c|}
\hline \multirow[t]{2}{*}{ Sektor } & \multicolumn{2}{|c|}{$\mathbf{R P}_{\mathbf{R}}$} & \multicolumn{2}{|c|}{$\mathbf{R P}_{\mathbf{S}}$} \\
\hline & Riil & Nominal & Riil & Nominal \\
\hline 1. Pertanian & 0,20 & - & 1,30 & + \\
\hline 2. Pertambangan \& Penggalian & 1,40 & + & $-0,37$ & - \\
\hline 3. Industri Pengolahan & 0,46 & - & 2,13 & + \\
\hline 4. Listrik, Gas \& Air Bersih & 1,10 & + & 1,37 & + \\
\hline 5. Bangunan & 0,90 & - & 0,61 & - \\
\hline 6. Perdagangan, Restoran \& Hotel & 1,05 & + & 1,01 & + \\
\hline 7. Pengangkutan \& Komunikasi & 1,81 & + & 0,82 & - \\
\hline 8. Keu. Persewaan \& Jasa Perusahaan & 0,18 & - & 1,88 & + \\
\hline 9. Jasa-jasa & $-0,03$ & - & 2,67 & + \\
\hline
\end{tabular}

Sumber: BPS Kabupaten Kepulauan Yapen (data diolah), Lampiran 1

Dari hasil perhitungan pada tabel berikut menunjukkan, bahwa sektor ekonomi yang mempunyai nilai $\mathrm{RP}_{\mathrm{R}}$ positif $(+)$ dan nilai $R P_{S}$ positif $(+)$ yaitu sektor listrik, gas dan air bersih dan sektor perdagangan, restoran dan hotel. Hal ini berarti pada periode tahun 2004-2008, sektor listrik, gas dan air bersih dan sector perdagangan, restoran dan hotel. merupakan sektor yang potensial baik di tingkat Provinsi maupun di tingkat kabupaten karena mempunyai pertumbuhan yang menonjol dari sektor ekonomi yang lain. Sedangkan hanya sektor bangunan yang mempunyai pertumbuhan rendah baik di tingkat Provinsi dan di tingkat
Dari hasil analisis MRP dalam konteks Kabupaten Kepulauan Yapen tersebut, menunjukkan bahwa sektor listrik, gas dan air bersih dan sector perdagangan, restoran dan hote/ merupakan sektor yang dominan pertumbuhannya. Selain itu, sektor tersebut juga menunjukkan peningkatan terhadap struktur pertumbuhan ekonomi. Hal ini mengingat sebagian besar penduduk di wilayah Kabupaten Kepulauan Yapen masih bergerak di bidang perdagangan, sehingga sektor ini mempunyai pertumbuhan yang menonjol dari sektor lainnya. Selain itu, sektor listrik, gas dan air bersih juga mempunyai pertumbuhan yang menonjol 
Analisis Potensi Unggulan Kabupaten Kepulauan Yapen: Agus Tri Basuki

Sehingga pembangunan di kedua sektor tersebut harus lebih ditingkatkan dan diperhatikan.

\section{Analisis Shift Share}

Analisis ini bertujuan untuk mengetahui kontribusi tiap-tiap subsektor terhadap Pendapatan Domestik Regional Bruto (PDRB).Analisis Shift-share dapat diguna-kan untuk mendeskripsikan trend agregat secara statistik, shift-share analisis mengklarifikasikan perubahan PDRB setiap saat dalam wilayah yang diperbandingkan dengan tiga kategori, komponen dalam membentuk shift-share diantaranya adalah PDRB di sektor tertentu (i) tingkat wilayah, laju pertumbuhan PDB tingkat nasional (rn), laju pertumbuhan PDB di sektor tertentu (i) di tingkat nasional (rin), dan laju pertum-buhan PDRB di sektor tertentu (i) tingkat wilayah.

Komponen perubahan secara nasional mempresentasekan komponen pembagian nasional untuk perhitungan dimana laju pertumbuhan regional yang telah mengalami perubahan diikuti perubahan secara tepat dalam tingkat nasional untuk semua sub sektor dalam tingkat nasional untuk semua sub sektor dalam periode penilaian.

Jika pertumbuhan di tingkat regional berbeda dengan nasional (berupa positip atau negatif dalam pergeseran PDRB), secara total pergeseran terdiri dari pergeseran struktural juga pergeseran mengenai pembagian proporsional.

Dampak perubahan PDRB dimana dalm perhitungan di tingkat regional berubah sesuai dengan tipe dari PDRB dalam sub sektor tertentu (termasuk cepat atu lambatnya laju pertumbuhan nasional). Pergeseran terdiri dari perbedaan dalam pergeseran juga pengetahuan tentang dampak regional dimana perhitungan PDRB regional berubah seiring dengan faktor lokasi di tiap regional.

Tabel 2. Perhitungan Shift-share Kabupaten Kepulauan Yapen Tahun 2007-2008 (Juta rupiah)

\begin{tabular}{|c|c|c|c|c|c|c|c|c|}
\hline & \multicolumn{4}{|c|}{2007} & \multicolumn{4}{|c|}{2008} \\
\hline & $\mathrm{Nij}$ & Mij & $C_{i j}$ & Dij & $\mathrm{Nij}$ & Mij & Cij & Dij \\
\hline 1 & 509,74 & 570,47 & 1388,26 & 2468.47 & $-1473,41$ & 3373,00 & 866,54 & 2766,13 \\
\hline 2 & 32,81 & $-106,22$ & 173,80 & 100,39 & $-93,18$ & $-278,35$ & 471,86 & 100,33 \\
\hline 3 & 34,30 & 94,61 & 135,72 & 264,62 & $-103,39$ & 284,10 & 217,97 & 398,68 \\
\hline 4 & 14,95 & 96,89 & 83,28 & 195,12 & $-45,70$ & 174,84 & 77,38 & 206,52 \\
\hline 5 & 402,66 & 2333,25 & $-593,36$ & 2142,55 & $-1158,85$ & 4557,76 & $-1454,28$ & 1944,63 \\
\hline 6 & 360,69 & 2296,31 & 720,05 & 3377,05 & $-1071,11$ & 4195,26 & 238,73 & 3362,89 \\
\hline 7 & 186,25 & 2090,70 & $-428,27$ & 1848,69 & $-554,90$ & 2938,57 & $-555,47$ & 1828,21 \\
\hline 8 & 143,75 & 610,22 & 1723,08 & 2477,05 & $-522,64$ & 2646,22 & 5072,25 & 7195,83 \\
\hline 9 & 863,14 & 577,15 & 7026,57 & 8466,86 & $-2470,85$ & 6244,75 & $-234,72$ & 3539,19 \\
\hline & 2548,28 & 8563,39 & 10229,13 & 21340,81 & $-7494,02$ & 24136,16 & 4700,26 & 21342,40 \\
\hline
\end{tabular}

Sumber : PDRB Menurut Lapangan Usaha Kabupaten Kepulauan Yapen, 2008 Keterangan :
Nij : Pengaruh Pertumbuhan Provinsi
Mij : Pengaruh Bauran Industri
Cij : Pengaruh Keunggulan Kompetitif
Dij : Analisis Shift-Share 
UNISIA, Vol. XXXII No. 71 Juni 2009

Sektor :

1. Pertanian

2. Pertambangan dan Penggalian

3. Industri Pengolahan

4. Listrik, Gas dan Air bersih

5. Bangunan

6. Perdagangan, restoran dan hotel

7. Angkutan dan Komunikasi

8. Keuangan, Persewaan dan Jasa Perusahaan

9. Jasa-Jasa

Dari tabel hasil analisis tabel 2., terlihat pada tahun 2008 terjadi pergeseran pembangunan di Kabupaten Kepulauan Yapen Provinsi Papua, artinya pergeseran pembangunan dapat dilihat dari laju pertumbuhan yang signifikan, hal ini dapat dilihat pada tabel diatas memiliki pengaruh keunggulan kompetitif kecuali, yaitu sektor bangunan, Angkutan dan komunikasi, dan jasa. Dari hasil analisis shift-share pada tahun 2008 secara keseluruhan dengan melihat pengaruh keunggulan kompetitif pada PDRB mengalami perbaikan dibandingkan dengan tahun 2006, tetapi secara keseluruhan semua sektor terjadi penurunan dibandingan tahun 2006 pada PDRB dalam wilayah Kabupaten Kepulauan Yapen.

\section{Analisis Location Quotient (LQ)}

Location Quotient (LQ) merupakan alat analisis untuk mengetahui ada tidaknya spesialisasi suatu wilayah untuk sektor (industri) tertentu.

$L Q=\left(E_{i j} / E_{j}\right) /\left(E_{i n} / E_{n}\right)$ dimana, $E_{i j} \quad$ Kesempatan kerja di sektor I di wilayah $\mathrm{j}$

$E_{j} \quad$ : Kesempatan kerja di wilayah j

$E_{\text {in }} \quad$ : Kesempatan kerja di sektor I di negara $n$

$\mathrm{E}_{\mathrm{ij}} \quad$ : Kesempatan kerja di negara $\mathrm{n}$ Interpretasi dari hasil perhitungan dengan formula tersebut adalah :

Tabel 3. Indeks Location Quotient (LQ) Kabupaten Kepulauan Yapen Papua, Tahun 2005-2008 \begin{tabular}{|l}
\hline 1. Pertanian \\
\hline 2. Pertamba \\
\hline 3. Industri $P$ \\
\hline 4. Listrik, ga \\
\hline 5. Banguna \\
\hline 6. Perdagan \\
\hline 7. Angkutan \\
\hline 8. Keuangar \\
\hline 9. Jasa-jasa \\
\hline
\end{tabular} 
Analisis Potensi Unggulan Kabupaten Kepulauan Yapen: Agus Tri Basuki

n Jika nilai $L Q>1$, maka wilayah j untuk sektor I ada spesialisasi (Tingkat spesialisasi wilayah > tingkat spesialisasi nasional)

$\mathrm{n} \quad$ Jika nilai $L Q=1$, maka wilayah $\mathrm{j}$ untuk sektor I ada spesialisasi (Tingkat spesialisasi wilayah $=$ tingkat usaha. Artinya, semua kabupaten/kota memiliki subsektor unggulan dan penetapan kawasan andalan berdasarkan persyaratan sektor unggulan dapat dipandang tepat.

Dari hasil perhitungan LQ diatas dapat disimpulkan bahwa Kabupaten Kepulauan Yapen memiliki keunggulan dalam semua

Tabel 4.Perhitungan Overlay Kabupaten Kepulauan Yapen Tahun 2004-2008

\begin{tabular}{|c|c|c|c|c|}
\hline \multirow{2}{*}{ Sektor } & \multicolumn{2}{|c|}{$\operatorname{MRP}\left(\mathrm{RP}_{\mathrm{S}}\right)$} & \multicolumn{2}{|c|}{$\overline{L Q}$} \\
\hline & Riil & Nominal & Riil & Nominal \\
\hline 1. Pertanian & 1,30 & + & 1,214043 & + \\
\hline 2. Pertambangan \& Penggalian & $-0,37$ & - & 0,02428 & - \\
\hline $\begin{array}{l}\text { Sumber: BPS Kabupaten Kepulauan } \\
\text { 3. Industrip engọahan } \\
\text { Keterangaha }\end{array}$ & $\begin{array}{r}\text { Yapen } \\
2,13 \\
\end{array}$ & ahun $2008(a$ & $\begin{array}{l}\text { ah) } \\
0,522314 \\
\end{array}$ & - \\
\hline 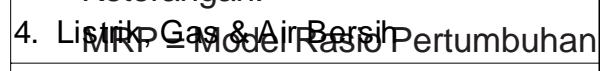 & 1,37 & + & 2,587062 & + \\
\hline 5. B Rifgy & vilay,âh & Studi - & 2,968519 & + \\
\hline 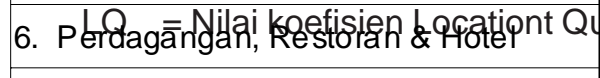 & $\begin{array}{r}\text { rotient } \\
1,01\end{array}$ & + & 2,384397 & + \\
\hline 7. Pengasplestiatis Kramasinikad) & 0,82 & sekłor, k & upali3325898 & pertał⿱十⿵冂⿱丷干)ang \\
\hline 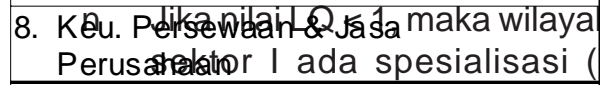 & $\begin{array}{l}\text { h juntuk } \\
\text { Tingsga }\end{array}$ & $\begin{array}{l}\text { penggali } \\
\text { Sektor y }\end{array}$ & 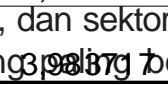 & $\begin{array}{l}\text { industri peng } \\
\text { sar memiliki }\end{array}$ \\
\hline 9. Jasa-jæłalesialisasi wilayah < & tizg,69a & unggulan & dalabosektger & asa (renata 4,9) \\
\hline $\begin{array}{l}\text { Spesialisasinasional) } \\
\text { Analisis LQ menunjukan bahwa } \\
\text { kota/kabupaten baik yang berad } \\
\text { kawasan andalan maupun kawasa } \\
\text { andalan, memiliki LQ yang lebih be } \\
\text { satu pada beberapa subsektor la }\end{array}$ & $\begin{array}{l}\text { a selurur } \\
\text { a dalam } \\
\text { an bukar } \\
\text { esar dar } \\
\text { apangar }\end{array}$ & $\begin{array}{l}\text { keuanga } \\
\text { serta sek } \\
\text { sektor pe } \\
\text { sektor pe } \\
\text { termasuk } \\
\text { tidak tern }\end{array}$ & $\begin{array}{l}\text { danjasa pe } \\
\text { bangunan ( } \\
\text { dukung ind } \\
\text { agangan, } \mathrm{h} \\
\text { ektor unggul } \\
\text { suk dalam } 3\end{array}$ & $\begin{array}{l}\text { usahaan (rere } \\
\text { erata 2,9). Sed } \\
\text { stri pariwisate } \\
\text { tel dan restor } \\
\text { an (rerata 2,39 } \\
\text { besar. }\end{array}$ \\
\hline
\end{tabular}

